\title{
Analysis of Influence of Spindle Speed and Feeding Speed to Tool Wear and Surface Roughness
}

\author{
D.L Zariatin, Reza Febriatna \\ Department of Mechanical Engineering \\ University of Pancasila, Jakarta \\ JIn. Raya Lenteng Agung, Srengseng Sawah Jakarta Selatan \\ Fax : (021)7270128 \\ Email: dedeliazariatin@univpancasila.ac.id
}

\begin{abstract}
One of the problem in metal cutting is tool wear. Its close relation to the expected tool life and quality of product, make tool wear become object of investigation. Eventough tool manufacturers always give recommendation on machining parameter, but they don't share the information on tool wear estimation. Some theory on tool wear has been proposed, but still need verification thru experimental works to determine parameters and constants of tool life typical to machine tool condition and machining process. In this research, experimental work and analysis of the influence of spindle speed ( $n$, $r p m)$, feeding speed $\left(V_{t}, \mathrm{~mm} / \mathrm{min}\right)$ and depth of cut $\left(a_{p}, \mathrm{~mm}\right)$ to surface roughness and tool wear on milling process using carbide ballnose with diameter of $10 \mathrm{~mm}$ on Al-7075 had been conducted. From the experiment, it can be concluded that tool wear has influence on surface roughness of product. Tool wear could be minimized by choosing optimum spindle speed and feeding speed.
\end{abstract}

Keywords: milling; run ballnose tool; spindle speed ( $n, r p m)$; feeding speed $\left(V_{f}, \mathrm{~mm} / \mathrm{min}\right)$

\section{INTRODUCTION}

Quality of a product in machining process is much influenced by geometric accuracy and surface roughness of the product. Surface roughness of product becomes an important parameter in order to achieve certain level of quality. Surface roughness has relationship with several factors; ones of them are proper machining parameter together with tool life [1]. Therefore, method to estimate product surface roughness and tool life become important. In general, it has been known that good surface roughness is a product of machining process by choosing low cutting speed and high feeding speed [2]. But, it will make the tool life become short and the roughness will also be bad because of wear on tool.

There several ways to estimate the value of surface roughness and tool life based on the choice of machining parameter, such as cutting speed, feed rate, depth of cut, and feed direction. One of them are mathematical modeling [3], detection of tool wear during machining process by using Fuzzy Logic, Artificial Neural Networks [3] and most conventional way is trial and error with many analytical methods such as Analysis of variant, Taguchi and etc. [4] [5] [3].

Surface roughness also got influence by characteristic of machine tool, like vibration, rigidity, environment condition, operation, etc. This makes available estimation cannot directly apply to available machine tool. Therefore, machine tool character test need to be performed for given work load.

In this research, surface roughness and estimation of tool life using Taylor equation was conducted to investigate relationship between spindle speed and feeding speed to surface roughness of product. Furthermore, chip also investigated to make sure that chosen spindle speed and feeding speed on machining process gave good result on product.

JEMMME | Journal of Energy, Mechanical, Material, and Manufacturing Engineering 


\section{Methodology}

In this research, experimental method was employed by machining Al-7075 using ballnose carbide tool coated with TiAIN of $10 \mathrm{~mm}$ diameter. On product of machining process, 3 observations were conducted by observing tool wear visually by employing digital microscopes, surface roughness by measuring surface roughness of product, and chips to verify executed machining process. The flowchart of research methodology was illustrated in Figure 2.1.

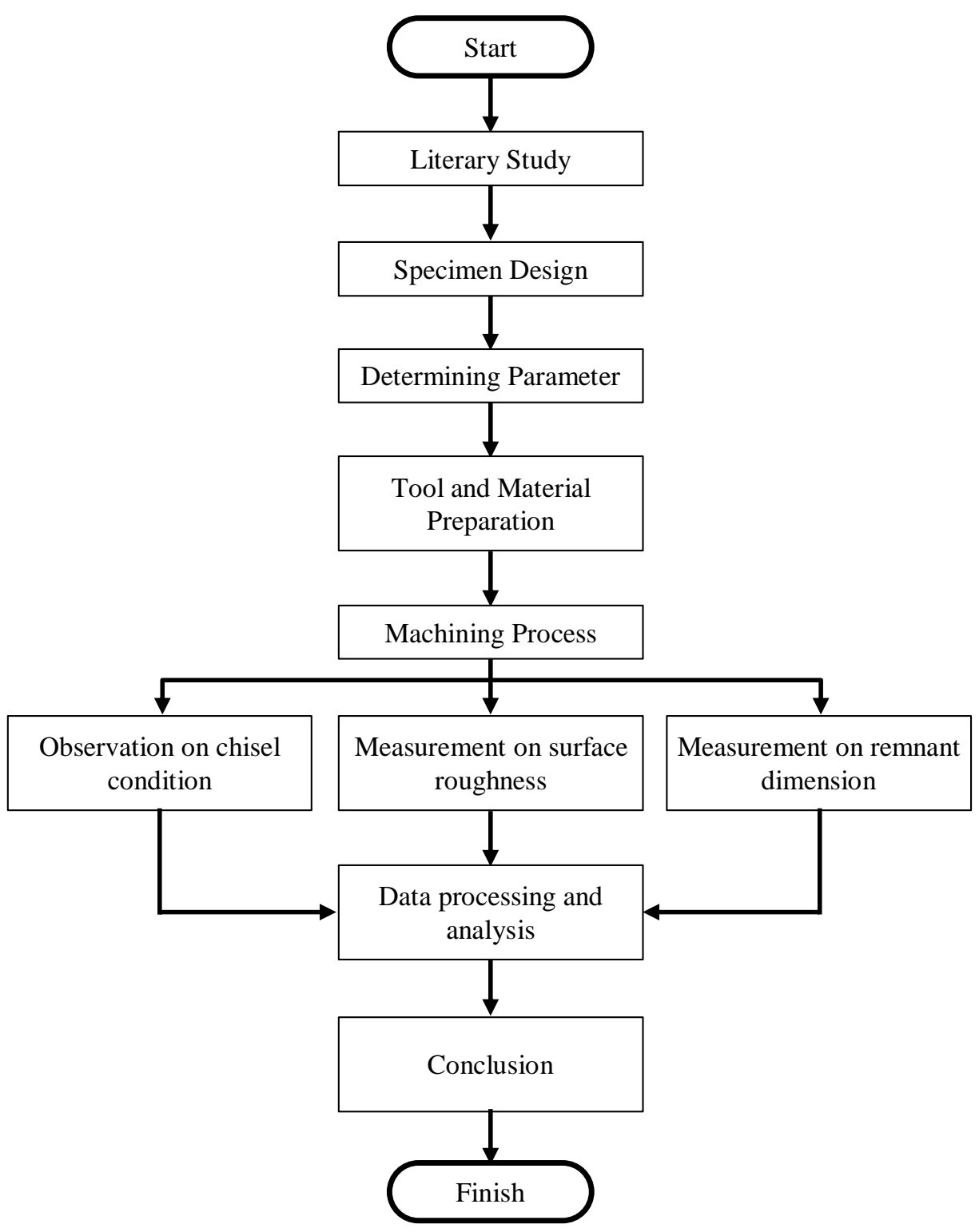

Figure 2.1 Flowchart of Research Methodology

\subsection{Set up and Experiment}

Al-7075 alloy is widely known aluminum alloy and has high strength [6]. Al-7075 alloy is one of material usually found on manufacturing of mould and dies for injection molding process. Al-7075 alloy also the variant applied for aircraft structural application. With these in mind, then this material were chosen for research.

To produce complex contour or weaving product such as mold and dies, Run ballnose tool is a right choice. But, because the shape of ballnose is not flat then contact 
between tool and workpiece is not always constant. Therefore, wear in the tool also is not uniform along tool's cutting edge. In this research, the machining process was conducted by CNC Milling EMCO - TU3A machine tool using Run ballnose carbide coated with TiAIN diameter of $10 \mathrm{~mm}$ (radius $5 \mathrm{~mm}$ ) and length $75 \mathrm{~mm}$, as depicted in Figure 2.2

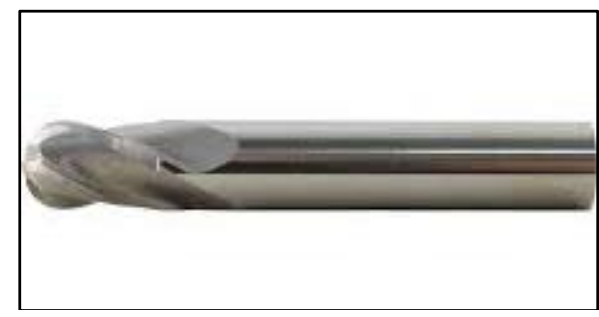

Figure 2.2 Run Ballnose Tool in Research

Based on literature review, the process steps (Run) and combination of machining parameter which consists of spindle speed ( $\mathrm{n}$, rpm), feeding speed ( $\mathrm{vf}, \mathrm{mm} / \mathrm{min}$ ) and machining time ( $\mathrm{T}$, menit), were decided as follows in Table 2.1.

Table 2.1 Process Run and Combination of Machining Parameter

\begin{tabular}{cccc}
\hline Run & $\mathrm{n}(\mathrm{rpm})$ & $\mathrm{V}_{\mathrm{f}}(\mathrm{mm} / \mathrm{min})$ & $\mathrm{T}$ (minutes) \\
\hline 1 & 500 & 400 & 70 \\
\hline 2 & 1000 & 200 & 70 \\
\hline 3 & 500 & 200 & 100 \\
\hline 4 & 1000 & 400 & 100 \\
\hline
\end{tabular}

To observe visually on tool condition, measuring width of wear, observing and measuring chip produced during machining process, Dino Lite Digital Microscope, with magnification until $250 \mathrm{~mm}$ with maximum resolution of 1.3 megapixels was employed. Meanwhile, surface roughness was measured by using Surface Roughness Tester Mitutoyo SJ - 201.

\section{Result And Discussion}

\subsection{Observation on Tool Condition}

After machining process for each Run was conducted, the next steps were observing tool condition and measuring wear. Wear measurement were conducted by measuring the length in the picture by scaling process software taken by digital microscope. From observation and measurement on wear, the results are as follows.

\subsubsection{Tool for Run 1}

From visual observation it was known on tool for Run 1, wear had been occurred up to $0.418 \mathrm{~mm}$ in depth, while for width of wear in the tool was up to $2.408 \mathrm{~mm}$. The wear was shown in Figure 3.1 below.
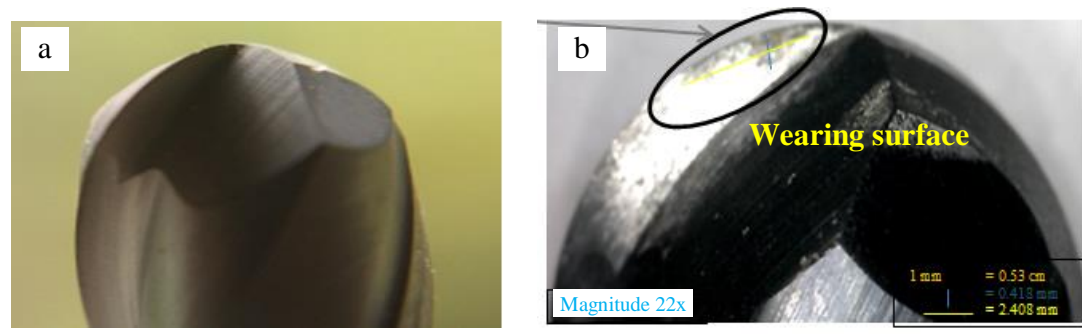

Figure 3.1 Condition of Tool for Run 1 (a) before machining run, (b) wear occurred.

JEMMME | Journal of Energy, Mechanical, Material, and Manufacturing Engineering 


\subsubsection{Tool for Run 2}

There were two areas or locations of wear on tool for Run 2, as depicted in Figure 3.2. The first area (I) had wear depth up to $0.339 \mathrm{~mm}$, and for width of wear in area (I) was $1.196 \mathrm{~mm}$. Wear on second (II) which occurred on tool for Run 2 had wear depth up to $0.377 \mathrm{~mm}$ and width of $1.451 \mathrm{~mm}$.
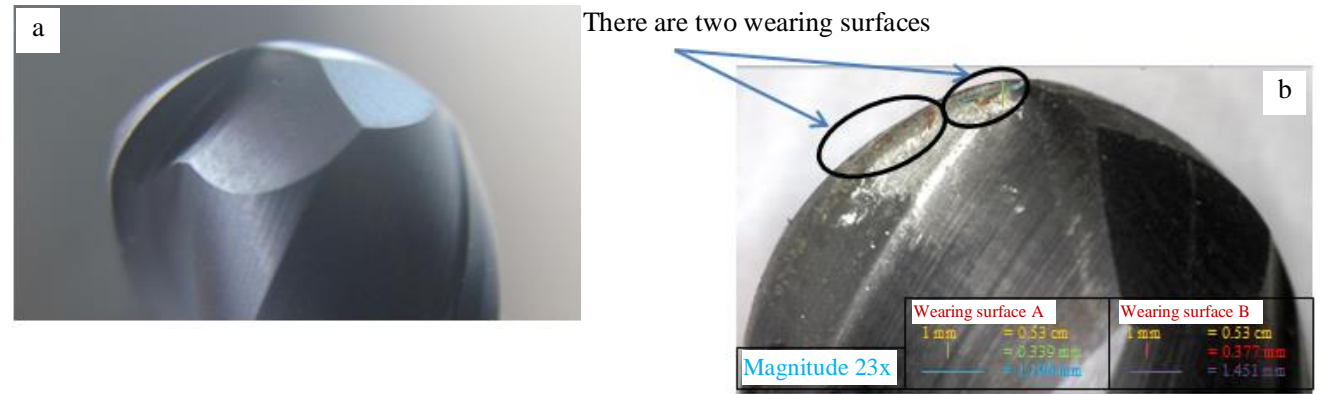

Figure 3.2 Condition of Tool for Run 3 (a) before machining process, (b) wear occurred.

\subsubsection{Tool for Run 3}

On the tool for Run 3, wear occurred up to $0.189 \mathrm{~mm}$ in depth, while width of wear on tool for Run 3 was $0.941 \mathrm{~mm}$, as depicted in Figure 3.3 below.

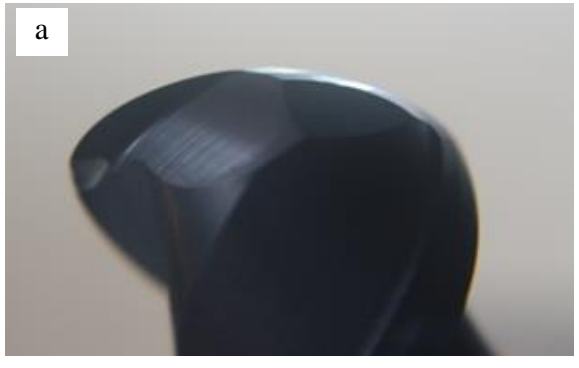

Wearing surface

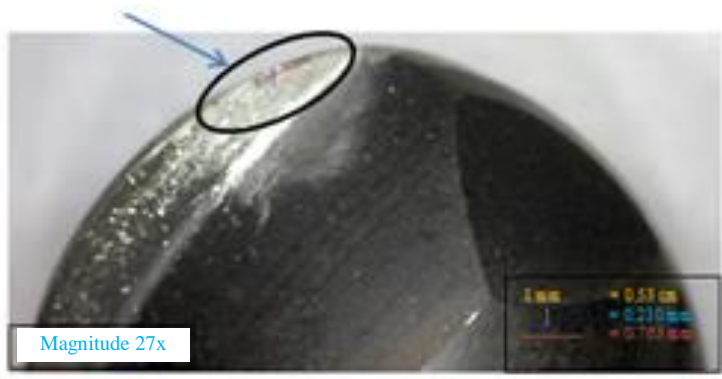

Figure 3.3 Condition of Tool for Run 3 (a) before machining process, (b) wear occurred.

\subsubsection{Tool for Run 4}

On the tool for Run 4, the wear occurred up to $0.210 \mathrm{~mm}$ in depth, while width of wear on tool for Run 4 was $0.763 \mathrm{~mm}$.
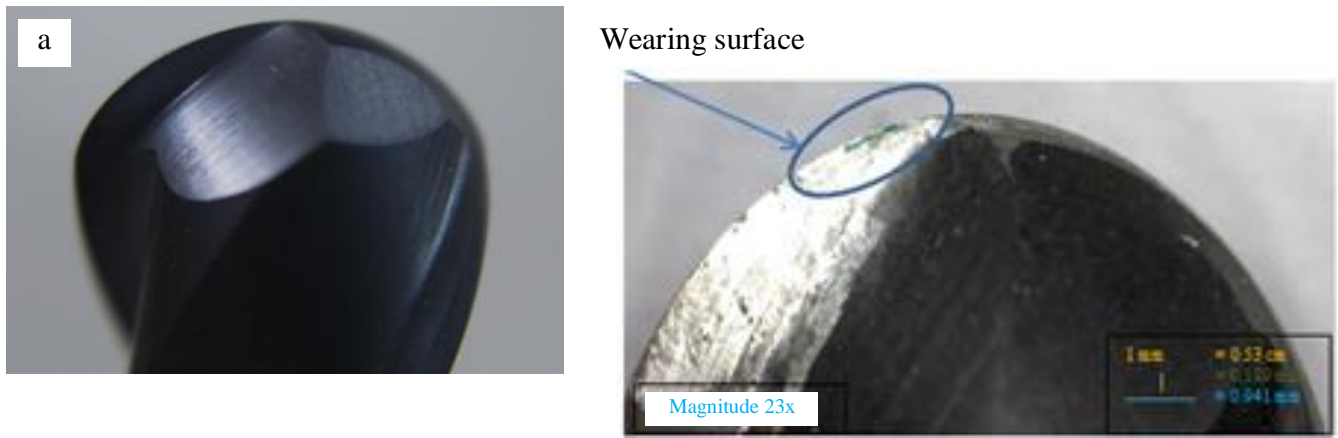

Figure 3.4 Condition of Run 4 (a) before machining process, (b) wear occurred.

From four observations conducted during machining process, tool for Run 1 has most significant wear in which up to $0.418 \mathrm{~mm}$ in depth, and $2.408 \mathrm{~mm}$ in width, a presented in Table 3.1. 


\begin{tabular}{cccccc}
\hline \multicolumn{7}{c}{ Table 3.1 Measuring Result of Wear on Tool } \\
\hline Tool & $\begin{array}{c}\mathrm{n} \\
(\mathrm{rpm})\end{array}$ & $\begin{array}{c}\mathrm{Vf} \\
(\mathrm{mm} / \mathrm{min})\end{array}$ & $\begin{array}{c}\text { T } \\
(\text { menit })\end{array}$ & $\begin{array}{c}\text { Depth of } \\
\text { Wear }(\mathrm{mm})\end{array}$ & $\begin{array}{c}\text { Width of Wear } \\
(\mathrm{mm})\end{array}$ \\
\hline Tool for Run 1 & 500 & 400 & 70 & 0.418 & 2.408 \\
\hline Tool for Run 2-I & 1000 & 200 & 70 & 0.339 & 1.196 \\
\hline Tool for Run 2-II & 1000 & 200 & 70 & 0.377 & 1.405 \\
\hline Tool for Run 3 & 500 & 200 & 100 & 0.189 & 0.941 \\
\hline Tool for Run 4 & 1000 & 400 & 100 & 0.210 & 0.763 \\
\hline
\end{tabular}

\subsection{Measurement of Surface Roughness}

Table 3.2 presents measurement results for surface roughness of the product of machining process. The highest value of surface roughness was on spindle speed of, $n=$ $500 \mathrm{rpm}$, and feeding speed of, $V_{f}=400 \mathrm{~mm} / \mathrm{min}$ eventhough the process is very short in duration. The best result was achieved when spindle speed was, $\mathrm{n}=500 \mathrm{rpm}$, and feeding speed was, $v_{f}=200 \mathrm{~mm} / \mathrm{min}$, eventhough longer time process was needed. This showed that choosing of right machining parameter will produce better surface roughness and longer tool life.

Table 3.2 Result of Surface Roughness Measurement

\begin{tabular}{ccccc} 
Measurement of & Tool for Run 1 & Tool for Run 2 & Tool for Run 3 & Tool for Run 4 \\
\hline 1 & 3.81 & 1.94 & 1.48 & 2.41 \\
\hline 2 & 4.15 & 2.00 & 1.34 & 2.08 \\
\hline 3 & 4.05 & 2.01 & 1.67 & 2.07 \\
\hline Average & 4.0033 & 1.98 & 1.4966 & 2.1866 \\
\hline
\end{tabular}

When dimensions of tool wear on Table 2.1 and surface roughness value on Table 2.2 was compared, it could be seen that Tool for Run 1 had highest width and depth of wear, and also hold true for value of surface roughness (low quality of surface finish). Meanwhile, Tool for Run 3 had lowest width and depth of wear, and also lowest surface roughness value. It showed the direct influence of tool wear to surface roughness.

\subsection{Measurement of Chip Dimension}

The objective of observation and measurement of chip was to know whether chosen machining parameter produce good machining process, in accordance with specification of chip shape in Figure 3.5. In Figure, chip shape 7 and 8 is the good one, while shape 4, 5,9 and 10 can be categorized as favorable.

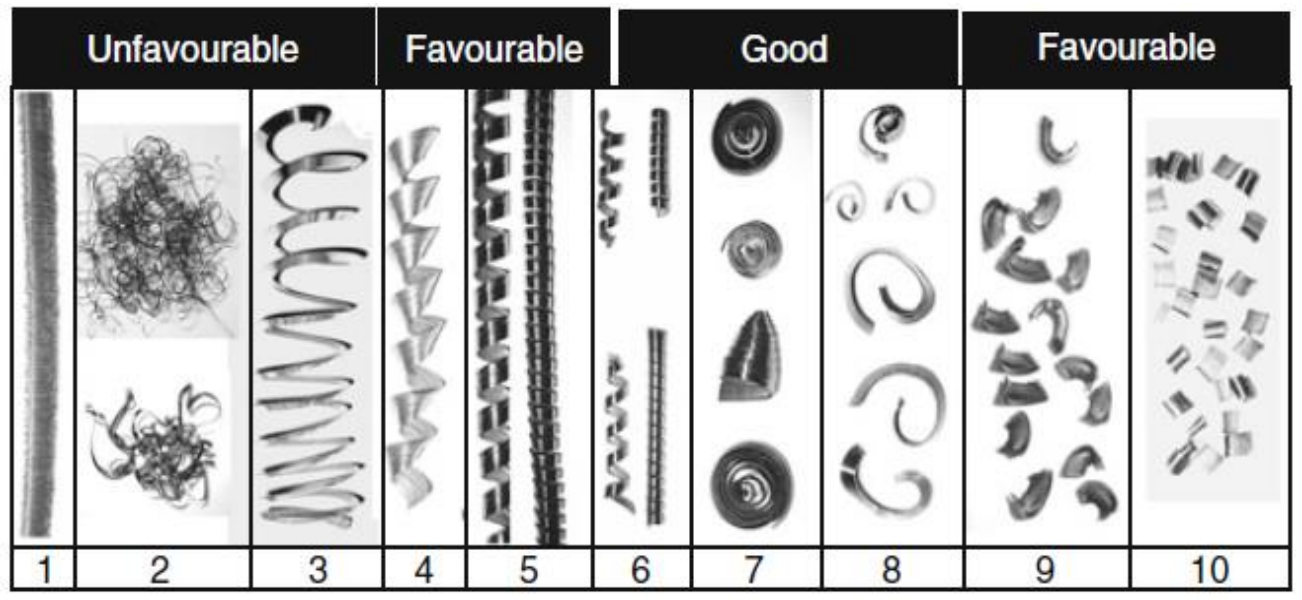

Figure 3.5 Shape of Chips [7] 

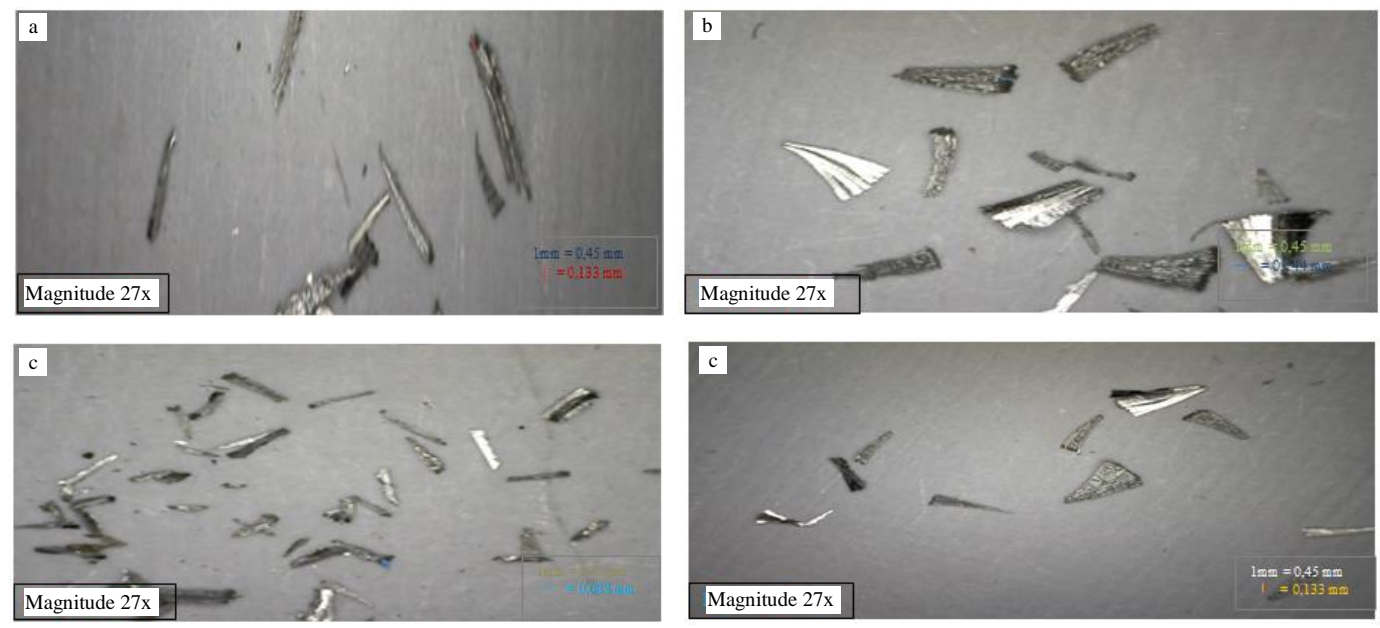

Figure 3.6 Chip produce from; (a) Tool for Run 1, (b) Tool for Run 2,

(c) Tool for Run 3, (d) tool for Run 4

From 30 measured samples, the average of chip thickness was presented in Table 3.3. From the result of observation on chip condition, the thickest one was for Tool for Run 2 with thickness up to $0.244 \mathrm{~mm}$.

\begin{tabular}{cc}
\multicolumn{2}{c}{ Table 3.3 Result of Measurement of Chip Thickness } \\
\hline Tool & Chip Thickness (mm) \\
\hline Tool for Run 1 & 0.133 \\
Tool for Run 2 & 0.244 \\
Tool for Run 3 & 0.088 \\
Tool for Run 4 & 0.133 \\
\hline
\end{tabular}

Comparing Figure 3.5 and Figure 3.6 showed that machining process in research produced chip close to the one of shape on number 10, which is discontinuous chips. Chip shape was not continue and it still favorable. This indicates that chosen machining parameter produce good quality of machining process.

\subsection{Calculation on Taylor Equation}

Taylor equation $V_{c} T^{n}=C$ is an equation which is, in general, used to estimate tool life. $V_{c}$ is cutting speed $(\mathrm{mm} / \mathrm{min}), T$ is cutting time (seconds), while $\mathrm{n}$ and $\mathrm{C}$ are Taylor constants obtained from experimental results. Results of calculation for four Run in this research was presented in Table 3.4, where the value of $n=0,25$ and $C=900$ [9].

\begin{tabular}{ccccc}
\multicolumn{5}{c}{ Table 3.4 Calculation of Tool Life According to Taylor Equation } \\
\hline Tool & $\begin{array}{c}\mathrm{n} \\
(\mathrm{rpm})\end{array}$ & $\begin{array}{c}\mathrm{V}_{\mathrm{c}} \\
(\mathrm{mm} / \mathrm{min})\end{array}$ & $\begin{array}{c}\mathrm{Vf} \\
(\mathrm{mm} / \mathrm{min})\end{array}$ & $\begin{array}{c}\text { T Taylor } \\
(\mathrm{min})\end{array}$ \\
\hline Tool for Run 1 & 500 & 15.7 & 400 & 0.133 \\
Tool for Run 2 & 1000 & 31.4 & 200 & 0.244 \\
Tool for Run 3 & 500 & 15.7 & 200 & 0.088 \\
Tool for Run 4 & 1000 & 31.4 & 200 & 0.133 \\
\hline
\end{tabular}

When compared with determined cutting time for this research to tool life based on Taylor Equation, the experiment's tools life was longer that theoretical one. Eventhough the tool life was longer, but when observed for tool wear it showed still in good condition and feasible to be used. 


\section{ConClusion}

Based on observation and analysis of machining process product, some conclusion could be drawn as follows:

1. Tool wear would directly influence the value of surface roughness. It was proved by comparison of value of width and depth of wear to surface roughness, where Tool for Run 1 had highest width and depth of wear and also had highest surface roughness. Tool for Run 3 had lower width and depth of wear and also the value of surface roughness.

2. In choosing of machining parameter, correct spindle speed and feeding speed would give longer tool life and better surface roughness. It was shown that best value of averages surface roughness $(\mathrm{Ra}=1.4966 \mu \mathrm{m})$ was achieved on spindle speed, $\mathrm{n}=$ $500 \mathrm{rpm}$ and feeding speed, $v_{f}=200 \mathrm{~mm} / \mathrm{min}$, even though for longer machining time (100 minutes).

3. The part in ballnose which mostly experienced wear was middle section of tool bit as shown in condition on Tool for Run 1, 2, 3 dan 4.

\section{REFERENCE}

[1] S. Rawangwong, J. Chatthong, R. Burapa and W. Boonchouytan, "An Investigation of Optimum Cutting Conditions in Face Milling Semi-Solid AA 7075 Using Carbide Tool," International Journal of Innovation, Management and Technology, vol. 36, 2012.

[2] R. Kumar, S. Kumar and S. Das, "Effect of machining parameters on surface roughness and tool wear for $7075 \mathrm{Al}$ alloy $\mathrm{SiC}$ composite," Internation Journal Advance Manufacturing Technology, vol. 50, no. 5, pp. 459-469, 2010.

[3] N. Agarwal, "Surface Roughness Modeling with Machining Parameters (Speed, Feed \& Depth of Cut) in CNC Milling," MIT INternational Journal of Mechanical Engineering, vol. 2, no. 1, pp. 55-61, 2012.

[4] A. M. Khorasani, M. R. S. Yazdi and M. S. Safizadeh, "Tool life prediciton in face milling machining of 7075 by using artificial neural networks (ANN) and Taguchi Design of Experiment (DOE)," IACSIT International Journal of Engineering and Technology, vol. 3, no. 1, pp. 30-35, 2011.

[5] H. Oktem, T. Erzurumlu and M. Col, "A study of the Taguchi optimization method for surface roughness in finish milling of mold surfaces," International Journal of Advance Manufacturing Technology, vol. 28, pp. 694-700, 2006.

[6] A. Ansyori, "Pengaruh Kecepatan Potong dan Makan terhadap Umur Pahat pada Pemesinan Freis Paduan Magnesium," Jurnal Mechanical, vol. 6, no. 1, 2015.

[7] Daniel, "Optimasi Parameter Pemesinan Proses CNC Freis terhadap Hasil Kekasaran Permukaan dan Keausan Pahat Menggunakan Metode Taguchi," Tugas Sarjana JurusanTeknik Mesin Universitas Diponegoro, 2009, 2009.

[8] F. Klocke, Manufacturing Processes 1, Springer Heidelberg Dordrecht London New York: Springer, 2011.

[9] V. Marinov, Manufacturing Process for Metal Product, Kendall Hunt Publishing, 2010.

[10] A. Widiyatmoko, "Pengembangan Perangkat Pembelajaran IPA Fisika Dengan Pendekatan Physics-edutainment Berbantuan CD Pembelajaran Interaktif," Journal of Primary Education, vol. 1, 2012.

[11] M. Prayito, "Pengembangan Perangkat Pembelajaran Matematika Humanistik Berbasis Konstruktivisme Berbantuan E-Learning Materi Segitiga Kelas VII," AKSIOMA, vol. 2, no. 2, 2012. 